\title{
Impact of fuel oil subsidy increase performance of cutting and regional
}

\author{
Ilham Thaief, M. M. ${ }^{1}$, Priyono, M. M. ${ }^{2}$ \\ ${ }^{1}$ Department Sciences Management, Faculty of Economic State University Makasar, Indonesia \\ ${ }^{2}$ Department Sciences Management, Faculty of Economic University PGRI AdiBuana Surabaya, East Java Indonesia \\ Email address: \\ Ilhamthaief@yahoo.co.id (Ilham Thaief, M. M.), Priyono.unu_sidoarjo@yahoo.com (Priyono, M. M.)
}

\section{To cite this article:}

Ilham Thaief, M. M., Priyono, M. M.. Impact of Fuel Oil Subsidy Increase Performance of Cutting and Regional. Journal of Human Resource Management. Vol. 2, No. 4, 2014, pp. 69-75. doi: 10.11648/j.jhrm.20140204.11

\begin{abstract}
The purpose of writing this article is to investigate the impact of rising fuel subsidies to regional and sectoral performance, while at the regional sectors directly affected by the rise in fuel prices is transportation and industrial sectors while sectoral performance can lead to the creation of value-added industry experienced a decline in both the short term and long term. On a positive position to reduce the burden of government spending in the budget and allocated for development purposes and others. But with the fuel price hike is certain to lead to what is called a spiral effect. Spiral effect that will arise is the increase in prices of all goods and services. By looking at the negative side, indicating that the activity of the sector in the economy can not be separated from other sectors in the economy, so the policy is directly related to the sector will impact on regional aspects which in turn will affect the macro economy.
\end{abstract}

Keywords: Impact of Subsidies, Increase Fuel, Sector Performance, Regional

\section{Introduction}

\subsection{The Fuel Price Hike will Impact the Future Look like}

In early May, Goldman Sachs issued a recent prediction that oil prices could reach 200 U.S. dollars before the end of this year. In fact, Goldman Sachs is not the first to come out with that figure. In advance, Stephen Leeb and Glen Strathy first warned of this possibility in his book published in 2006: The Coming Economic Collapse: How You Can Thrive When Oil Costs \$ 200 a Barrel \$.

Assumption that oil prices are listed in the State Budget (Budget) Change newly established in April is 95 U.S. dollars. At current prices, the benchmark has missed more than 30 U.S. dollars. Without the increase in fuel prices, soaring energy subsidy of 187 billion to 250 billion, almost. If the price crept up to 150 U.S. dollars, the subsidy could ballooned to around 300 billion. (Faisal Basri: 2008) (1).

Era Muslim.com., 2008 (2), Stating the fuel price hike is actually a small part of the oil and gas sector liberalization efforts in the country. Later, Pertamina, Oil company which has been the sole manager that will compete with more than 40 foreign oil and gas companies that had issued a permit to open a 20,000 General Fuel Filling Stations (gas stations) across Indonesia, the price of international standards.

To determine the impact of fuel price hike (Bazwir: 2008) (3), states have to know the exact background and motivation. If, for correcting the background that are not well targeted, in order to save fuel consumption, including to prevent smuggling and so on. The reason is not quite right, not an explanation but it obscures the real motives. The real reason is the government since 1998 LOI sign where we are subject to the IMF to release fuel prices to international prices. It's actually not about the hike, but about the process of gradually removing fuel prices according to the market price of the IMF line, and it was followed up by the government since 1999 has made a new draft oil and gas law, but at the time clashed with Pertamina

Then in 2000, America entered through USAID providing debt to begin the process of liberalization of the oil and gas sector. One that is done in the framework of liberalization that USAID is preparing a draft of the new law, in collaboration with the IDB and the World Bank set up the whole energy sector reform. In the oil and gas law is 
clear, Article 28 paragraph 2 of Law said the oil and gas fuel prices released to the market mechanism.

\subsection{Performance Impact on Sectoral / Industry}

(Elijah Radianto, 2008)(4), states that the policy of fuel subsidy reduction or increase in fuel prices, in fact have a positive impact, both to reduce the burden of government spending in the budget and allocated for development purposes and others. But with the fuel price hike is certain to lead to what is called a spiral effect. Spiral effect that will arise is the increase in prices of all goods and services.

Sectors directly affected by the rise in fuel prices is transportation and industrial sectors. In the transportation sector, for example, a result of rising fuel prices, will raise fares practical passenger and freight services, although it has been raised before. Likewise in the industrial sector, with the rise in fuel prices will affect the production process than the use of fuel, also affect the transport sector for transportation of raw materials and distribution of transportation products. This condition will certainly affect the cost of production. With this situation can be predicted that the selling price will increase, which in turn will push the rate of inflation (cost push inflation), ( Elijah Radianto, 2008) (4)

During this time, various world case studies to demonstrate that the rise in oil prices is almost always certain to cause adverse effects to the economy. Beginning with production function analysis that connects the output to the input of capital, labor, and energy, indicating that the impact of rising world oil prices would be followed by a decline in global oil production and then followed immediately by a decrease in productivity and will indirectly reduce the level of wages that result in reduction of working hours of employees ( Rasche and Tatom, 1977, 1981, Burbidge and Harrison, 1984 ; Sritini, 1985, 1994; Gisser and Goodwin, 1986; Kim and Loungani, 1992, Raymond and Rich, 1997, Hamilton, 2000). (5).

In Indonesia, according to the results of studies that have been done by Handoko and Susilo (2000), (6) shows that with the 40 percent decrease in fuel subsidies, may cause the performance of sectoral or industry experienced declining value creation in both the short and long term. By looking at the negative side of the above, suggests that the activity of the sector in the economy can not be separated from other sectors in the economy, so the policy is directly related to the sector will impact on regional aspects which in turn will affect the macro economy

Thus, it is clear that the increase in fuel prices will lead to inflation is the rise in general prices, where prices are generally determined by demand and aggregate supply. Therefore, if the rate of growth of aggregate demand exceeds aggregate supply growth rate will give rise to inflation which is driven by demand (demand pull inflation) cost push inflation and vice versa.

The development of aggregate demand can be influenced by several factors including: banking monetary first, second, government (fiscal) and abroad (balance of payments ). While influenced by the aggregate supply of human resources, technology and other resources. Decline in the quality and quantity of resources could increase production costs so as to shift the aggregate supply up (cost push inflation). Aggregate demand consists of household expenditure (consumption), investment, government spending and foreign sector (exports minus imports) may change as a result of the influence of monetary policy, fiscal and balance of payments. Monetary and credit policy is expansionary

Stimulate aggregate demand rises. If the aggregate supply kink sector (rigidities) inflationary pressures will emerge .Basic ally, according to the logic (Radianto Elija, 2008) (4) are as follows : Increase in output (economic growth ) will affect the increase in aggregate demand (AD) with the assumption of fixed aggregate supply (AS) then it will lead to increase in prices of goods and services (inflation) and the increase / growth will also affect the demand for goods and services imported by the assumption that exports remain, it will cause a deficit in the current account.

\subsection{Impact on Regional Performance}

If we look closely, macroeconomic conditions today seem to have shown some indicators are somewhat relieved, although still necessary improvements here and there. One indicator is the success of the government's economic achievements via visible on Gross Domestic Product (GDP) annual (yoy $=$ year-on- year) in the range of 6.13 percent to 6.3 percent. While the quarterly GDP (quarter to quarter = qtq) of 2.15 percent. Likewise, unemployment fell from 9.75 percent to 8.46 percent compared with 2007. Percentage of poverty also declined from 16.58 percent to 15.42 percent compared to last year.

Nevertheless (Elijah Radianto, 2008) (4) states, the largest percentage seems to support economic growth is derived from the level of consumption that comes from upper middle-class citizens, not the lower class. Likewise, although the poverty rate down, but in general the level of poverty is strongly correlated with the rate of inflation. It means that, if inflation is high, the poverty rate would rise again.

By looking at some of the indicators above, as well as the adverse impacts that would arise as a result of inflation, which seems to be continue as a result of their religious holy days that it is possible to suck huge amounts of liquidity in the market so it will push the inflation of the side demand. Not to mention going to the increase in LPG prices, and the need to watch out particularly well against the regional performance.

Based on the study results Handoko and Susilo (2000), (6) shows that the decrease in fuel subsidies by 40 percent, can lead to negative performance on regional aspects, both in the short and long term. In terms of aggregate output (Gross Regional Domestic Product $=$ GDP), shows that each province has decreased between 2.53 percent to 0.30 percent. This means that, if the government reduced 
subsidies in a large percentage, it is certain there will be a decrease in national economic growth through GDP in 2008 .

Thus, in order to suppress the spiral effect of raising the prices of all goods and services, as well as the decline in output and employment, it is absolutely necessary that policies to reduce the cost of production and price. In addition, if the government will still raise the price of LPG, to reduce the burden on the state budget, then the decline as much as possible done gradually or slowly, with the principle of cross subsidy so as not to overload the sectoral and regional performance, which in turn can spur economic achievements to Overarching both directions.

\section{Basic Theory}

According Suparmoko (2003), (7) may be direct subsidies (in the form of cash, interest-free loans ,etc. ) or indirectly ( liberation depreciation, discounted rent, etc. ). Such subsidies can be: production subsidies, the government shut down some of the costs of production to boost output of certain products and to reduce prices ; subsidy revenue, given the government through government transfers to improve the living standards of the majority age specific groups. While Kamaludin (2003),(8) states that although it has the merit subsidies to businesses and the public interest, but the subsidy also has some drawbacks, including :

a. Subsidies may result in unfair competitive relationship between the various business activities, because the distribution can not be done in a fair and equitable.

b. Subsidies can lead to wastage of both capital investment and excess facilities.

c. Subsidies can lead to inequities between service users and taxpayers who do not directly benefit. So in general, the subsidy aims to increase output, demand and productivity and maintaining economic stability, especially price stability. With the expected subsidy community staple available in sufficient quantities with prices stable and affordable by the community (Finance and Budget Memorandum, 2010; Handoko and Patriadi, 2005; Norton, 2004; Kasiyati, 2010). (9).

The impact of changes in input prices of fuel, the production in general, can be studied through the theory of input substitution and output effects. According to the graph, the substitution effect theory explanation of input and output is presented in Figure 1 (Ferguson and Gould, 1975 in Astana, 2003). (10) For simplicity it is assumed that there are two types of capital input (vertical line) and fuel (horizontal line). Initial equilibrium production occurs at point $\mathrm{P}(\mathrm{k} 1, \mathrm{ml})$. Output level is indicated by isoquant curve ISQ1 and cost levels by the isocost KM1. Level of input use and the use of fuel by $\mathrm{m} 1$ capital of $\mathrm{k} 1$. If the government reduces the fuel subsidy, the fuel input prices will rise. At the level of costs is available, manufacturers are trying to maximize output by reducing fuel input. Reduction of fuel input is indicated by a shift of the isocost
KM1 to KM2. Further reduction in fuel input will cause the output level also decreases, which is shown by the shift of the isoquant curve ISQ1 to ISQ2. Changed the balance of production, ie from point $\mathrm{P}$ to point $\mathrm{R}(\mathrm{k} 3, \mathrm{~m} 3)$ where the rate of fuel use by $\mathrm{m} 3$.

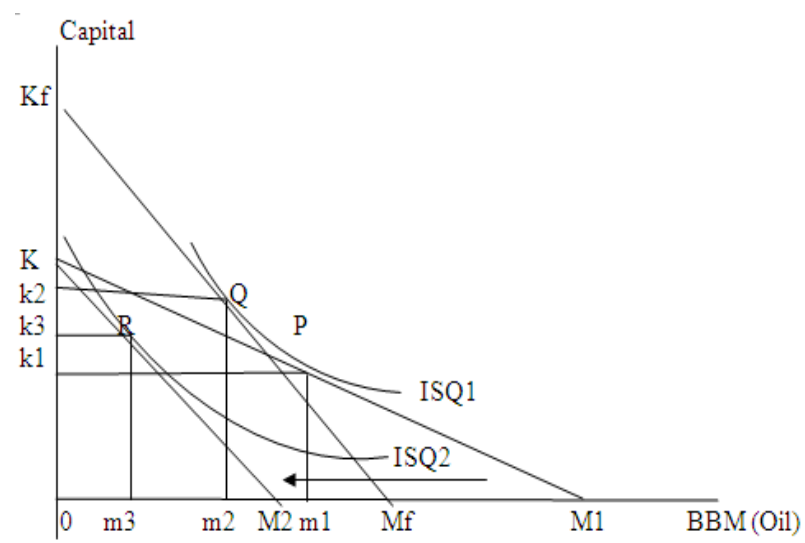

Figure 1. Input and Output Substituti on Effect Due to decrease in Fuel Price Subsidy.

\subsection{Economic Performance}

For more than three decades, macroeconomic theory and its application in the economy has grown better, where the principles of macroeconomic theory underlying many macroeconomic activity itself (Chari and Kehoe, 2006). (11)

According to Mankiew (2003), (12) there are several variables that can be used to measure the performance of the economy, but there are at least three important macroeconomic variables and a lot of concern that the economic experts of national income or GDP, price stability or inflation, and unemployment. Pohan (2008) (13) adds that the balance of payments or BOP (Balance of Payment) to be one of the targets of macroeconomic policies in addition to those already mentioned. Economic stability can be seen from the impact of other macroeconomic variable shocks to key macro economic variables.
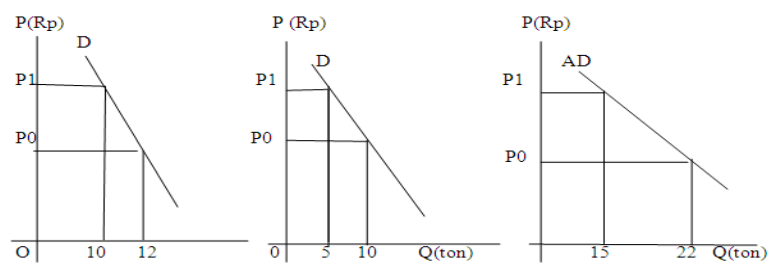

Source:Mankiew (2003).

Figure 2. Aggregate demand curve.

According to Stiglitz (2013), (14) an item is classified as a public good if it meets one or both of the following characteristics:

a. Non-rival consumption, is goods that can be consumed by an individual without reducing the opportunity for other people to consume, or be consumed together. 
b. Non-exclusion, that nothing can hinder a person to consume such goods.

The authors describe the illustration below the indifference curve of public goods and private goods. As follows::

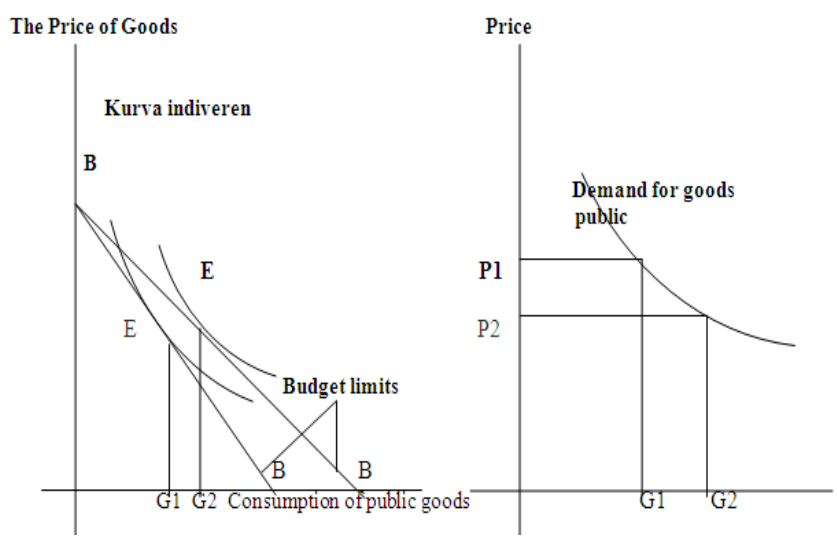

Sources: Stglitz (1999)

Picture indiveren curve public goods and private goods.

\subsection{Problem Disparity}

Say measures such spectacular success to the fullest. Is the core then the problem is solved ? Faisal Basri : 2008 (1) states are not at all. Because, the problem will occur throughout the eternal price disparity, ie, between the price set by the government and economic price. Nobody could be against the law of the market. Distorted ( distortions ) will increasingly rampant that the government set prices far (lower) than the economic price. First, the increase in consumption will be uncontrollable because the relative price of fuel in the eyes of consumers is very low. This increase in consumption has occurred. Indonesian consumers do not care if the price

World oil skyrocketed because of the price they pay in Indonesia budge. So, be classified Indonesia as the most wasteful country in the world in terms of energy use. Opinions Kwik Kian Gie( 2006 ), ( 15 ) the calculation of the crude oil is under the surface of the earth being sucked up into the surface earth. For that there is the cost, which is $\mathrm{Rp} X$ / liter. Already crude oil is above the earth's surface to be processed into gasoline. It costs USD \$ Y / liter. The gasoline must be transported to the gas station pump It costs Rp Z/ liter. Thus, Rp. X + Rp.Y + Rp. Z = 10 USD a barrel equal to one barrel of 159 liters. If the exchange rate of one U.S. dollar equal to Rp 8,600, then the entire.costs for a liter is $(10 \times R p 8,600)$ : $159=\mathrm{USD} 540.88$, rounded up toRp540/liter.

\section{Discussion}

Through this discussion the author of article sciting the basis for calculation of Kwik Kian Gie (2012) (16) as follows:

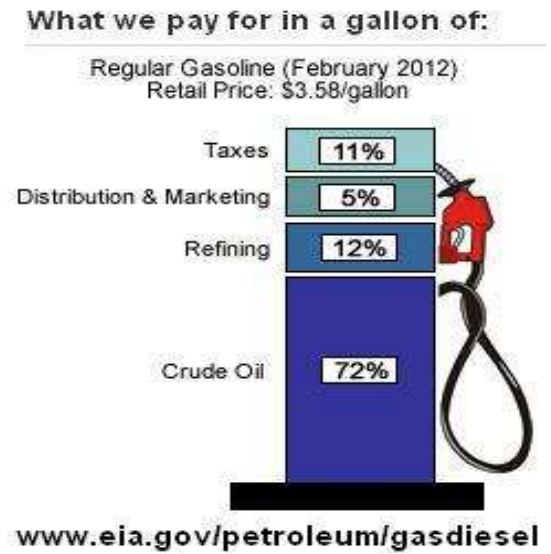

If you look at the calculations presented by Kwik Gian Gie it is true. The real cost of oil production from oil digging, refineries, and distribution to the Petrol Station by KKG is U.S. \$ 10/barrel. It's good to be pushed just so U.S. $\$ 15 /$ barrel to benefit Neo liberalism advocates say the fuel subsidy exists. It already includes a sizable profit for operators and distributors. Those who doubt the figure can see the data component of the cost of U.S. government website : http://www.eia.gov/petroleum/gasdiesel. ( 16 ) In situ crude oil costs explained $72 \%$ of the sale price, $12 \%$ refining, distribution and marketing of 5\%, $11 \%$ tax. Put a rate 1 U.S. $\$=\operatorname{Rp~10,000~and~} 1$ barrel $=159$ liters. If the oil price $\mathrm{Rp} 4.500 /$ liter, meaning 715.500/barrel USD or U.S. \$ 71/barrel. So the production cost of only U.S. \$ 15/barrel and selling price of U.S. \$ 71/barrel, the Government actually profit U.S. \$ 56/barrel. Imagine if our 1-year oil production of 350 billion barrels. Government profit of U.S. \$ 19.6 billion or Rp 196 trillion / year. That is if the price disposable " subsidy " Rp 4.500/liter. If you use Pertamax price is Rp 9000/liter, the government profit of 392 billion / year. But what about the world oil prices as U.S. \$ 120/barrel ? Have not we lost U.S. \$ 79/barrel ? True if we are not oil producing countries such as Singapore or Japan to buy oil from other countries.

But Indonesia produces its own oil by 907 thousand barrels / day. Perhaps even if not " fool" foreign oil companies that manage $90 \%$ of our oil. While the need for fuel ' subsidy' was only 723 thousand bpd ( 42 million kilo liters / year ). Sofortunately still government. Want to world oil prices rose to U.S. \$ 200/barrel was actually the cost of oil production in Indonesia will not change. At best only U.S. \$ 15/barrel. Just a thought that is different than the Islamic economists populist or Neoliberal economists in favor of the foreign oil companies. Although fortunately, they still say loss.

Though the oil is common property of the people of Indonesia. Not owned by the oil companies or the government of Indonesia. So not worth selling for

"International" .http://www.mediafire.com/?jez4ynm4vzt ( 17 )The people know that even though world oil prices U.S. \$ 200/barrel, Indonesia still profit at Rp 4500/liter or U.S. \$ 71 barrel considering production costs only U.S. \$15/barrel. 
See a comparison between different views of understanding profit / loss on sale of oil among economists thought Islamic / People with Neoliberal economists who influenced Jewish. At the time of the Prophet there are Jews who sell water at high prices to the people. Please note, until now the price of water in Saudi Arabia is more expensive than oil prices because the water there is very rare. But after the water wells purchased Muslims, the Prophet distributed free to the people. This is because people should be able to get their needs easily. Comparison under the assumption :

1 barrel $=159$ liters

1 U.S. $\$=$ Rp 10,000

Indonesia's oil production $=907$ thousand bpd

Needs fuel " subsidy " with the price of Rp 4500/liter (U.S. $\$ 71 /$ barrel) $=740$ thousand bpd general costs of Indonesia's oil production $=$ U.S. \$ 15/barrel.

\begin{tabular}{llccc}
\hline Information & \multicolumn{4}{l}{ WORLD OIL PRICES (USS/BRL) } \\
\hline Perception of Profit / Loss & 60 & 120 & 200 & 400 \\
Islamic economists / People & 56 & 56 & 56 & 56 \\
Neoliberal economists & 11 & -49 & -129 & -329 \\
\hline
\end{tabular}

Lay people watched as the oil production cost U.S. \$ 15/barrel and sold for Rp 4500/liter (U.S.\$ 71/barrel) as a profit of U.S. \$ 56/barrel. But looking at the Neolib loss of U.S. \$ 49/barrel time World oil prices rose to U.S. \$ 120/barrel. When world oil rose to U.S. \$ 400/barrel also considered a loss of U.S. \$ 329/barrel when in fact still profit. Anggito Ahimanyu, one of the neo-liberal fundamentalist Indonesia who always insisted on raising fuel prices due to "reduce the burden of fuel subsidy", admits that

there has never been there in the fuel subsidy. " There is still a surplus of receipts over the costs of fuel, " he said in a talk show on TV One on Monday ( 13/03/2012), related to the planned increase in fuel prices due to rising world fuel prices. Anggito be one of the speakers with Kwik Kian Gie and deputy minister of Energy and Mineral Resources. Anggito probably would never give such recognition if it is not because there is Kwik Kian Gie, who has long expressed his opinion that the issue of " subsidy " is a public deception, and repeated that opinion in the above program talk show,. http://muslimdaily.net/opini/opini17/anggito-abimanyu-selama-ini-tidak-pernah-ada-subsidibbm.html ( 18 ) If any " true " loss of government, Pertamina could be forced to buy oil Indonesia, $90 \%$ is managed by the U.S. oil company like Chevron and Exxon with New York prices. If so, the solution is in the Nationalization. China and Norway manage their oil to their state. Saudi Arabia, Iran, and Venezuela also has nationalized the foreign oil companies that used to monopolize their oil. Now they prospered because revenues increased due to not being lied to by firms foreign oil. Http://infoindonesia.wordpress.com/2009/06/30/forwealth-natural-robbed-Indonesian foreign- will continue - poor / (19) over $90 \%$ of our natural wealth controlled by foreigners, as long as it did Indonesia destitute. Oil prices rose, rather than profit or loss even as the story " subsidy " to gain weight. Oil prices fell too " Complaining "for reduced admission. Never got so thankful God torment continues. "Lord proclaims:" Except ye thankful, I will add (favors) unto you, and if you deny (my favor), then verily, My punishment is severe. " [ Ibrahim7 ] ( 20 ) The act of gratitude we with wealth our nature is to manage it themselves so they can enjoy all the results. Not just ignore it and handed it to the stranger and eventually foreign who enjoy the results while the Indonesian people so poor and destitute.

KKG proposed rate is actually very sensible. Moreover, according to the Statistics Agency of Energy (Energy Information Administration), 42 gallons of crude oil Refinery will produce 45 gallons (6 \% more) such as Gasoline, Diesel, and Avtuur which was very expensive.

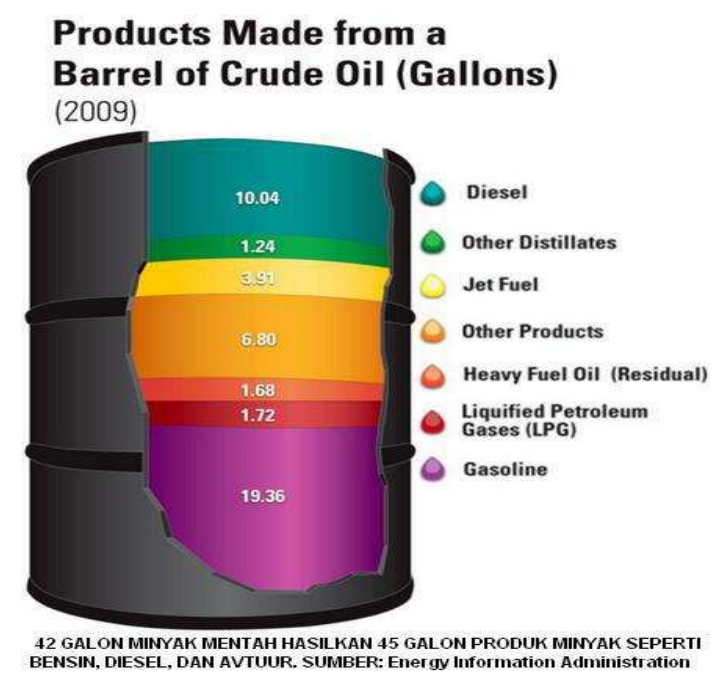

\section{Conclusion}

With increasing fuel prices if the government believes all grounds can be realized by properly secured ? The fuel price hike is only made worse the suffering people of Indonesia. Rising fuel prices will automatically raise the price of all the needs of the community; though, their income is fixed. Efforts should address the governance and financing of the state budget is increasing, the government can take advantage of the abundant natural resources in the country. In addition, efforts to increase domestic oil production should also be performed. If we see, only 50 percent of oil production in the country is processed bias, while the other 35 percent left to the contractor to pay the processing cost recovery in overseas oil, and the remaining 15 percent of production for profit sharing with the contractor. For the future, the government should pursue policies by processing all the oil refineries in the country. In other words, the government should take steps to download the takeover of 35 percent to pay for cost recovery. If 85 percent of domestic oil production is processed, then it is sufficient fuel for domestic needs and help the efficiency of the budget. In addition, the 
government needs to do some other things that increase the windfall profit tax or additional tax on oil company profits due to crude oil price spike, cut oil trade flows in order to export - import, and apply additional taxes to private fourwheeled vehicle over its use of the fuel subsidized. With it the problem of rising oil prices and the budget will be resolved properly realized.

\section{Production peaks in Indonesia}

The above is an approxi mate peak oil production for then tire world. And what about the peak in Indonesia? According to BP publication entitled "Statistical Review of World Energy 2005", the highest Indonesian oil production occurred in 1977, with an average of 1685 thousand barrels/day. After that, Indonesia's oil production has never again reached that number. In 2004, Indonesia's oil production is only at 1126 thousand barrels/day. This number has been under Indonesia's fuel consumption numbers for 1150 thousand barrels/day. Here is a graph of the production and consumption of fuel in Indonesia from 1965 to 2004 based on data from BP:

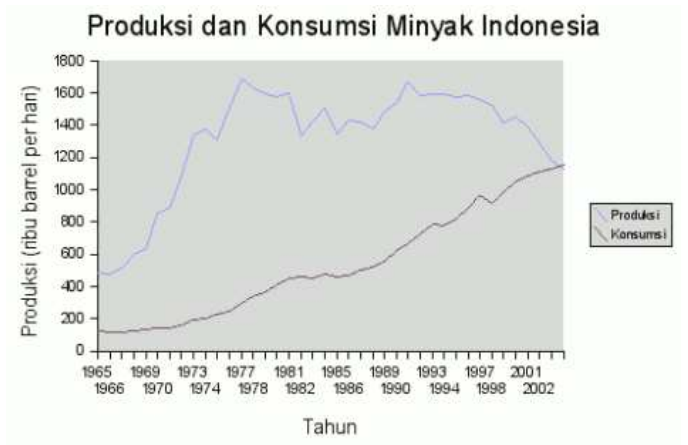

According to BP, Indonesia's oil reserves that can prove its existence is only about 4.7 billion barrels.

\section{Suggestions}

If it refers to the basis stated by Kwik Kian Gie, 2008., Indeed no subsidy is given to the public, the current is direct cash assistance to people who are given three months The impact would be even better if accompanied by compensatory programs aimed at poor households. This is actually recommended from research LPEM, ( M Ikhsan, 2005) ( 21 )

Back to the question above, the most wins of this policy is that poor households receive compensation and in fact the most disadvantaged group of middle income class income group is $40 \%-60 \%$. If they pay tax household income is actually being offset from the beginning to the increase in non-taxable income ( taxable income ) by $300 \%$ since January 2005. Just unfortunately if you look at the structure of individual tax revenues, the majority of this group is not a permanent employee unless the taxpayer includes factory workers.

Who actually need the extra protection is house hold before this policy is enforced quite near poor, especially in urban areas. There fore M. Ikhsan, 2005. ( 21 ) since the beginning of the coverage requested that poor rice expanded to encompass not only the poor but the BPS criteria households on it. If we worry about corruption by government officials, which we ask be done, especially to that exist in urban areas. Some have been doing this profession in distributing rice from WFP well. Additional count poor rice program from 8.6 million to 10 million families estimated to reach 700 billion. And if the rice used is domestic rice, it will increase the volume of government procurement of rice and will raise the price of rice and grain in rural areas and will help invigorate the rural economy. Unfortunately this advice then lose to other programs outside of education. But still may change due to proposed so far is only a government proposal. Parliament is likely to change.

\subsection{Address the Increase in Fuel}

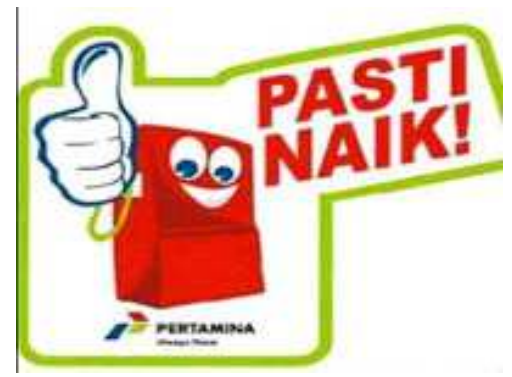

All parties would feel difficulty when fuel went up. Because if fuel rises, all basic needs will also increase. However, most people in the face of this problem wrong. Everyone wants to make herself heard by the authorities. The demonstration was that was the solution. no one has to think, why our leaders can choose the way to raise the fuel ? no one wants to contemplate, what we really want our beloved president torment and even kill their own people? Then why do not want to address this with the patient?

\subsection{Not Protesting}

Shaykh Dr. Sholeh Al Fauzan said, "As for the demonstration", Islam did not approve it. Because the name demonstrations always cause chaos, eliminating a sense of security, causing loss of life and property, and look down upon Muslim rulers. While religion is a religion that regular and discipline, also always wanted to eliminate the hazard.

Even worse if the mosque to be a place opposite to the location of demonstrations and occupation of public facilities, then this will add to the damage, harassing mosque, eliminating the glory of the mosque, to scare people and make dzikir prayer to God in it. Though the mosque built for ,dzikir worship God, and to find peace.

Therefore, it is mandatory for every Muslim to know these matters. Muslims must not deviate from the right path by following a tradition that comes from the unbelievers, to follow the call heretical, simply follow the Gentiles and the people who love to make mischief" [ Fatwa of Shaykh Salih bin ' Abd Al- Fauzan ]. 


\subsection{Rational Thinking in Finding Solutions}

The article's author is more interested in the solutions offered by the minister Dahlan Iskan, rather than to waste the energy to march. So to counter the rise

Fuel prices ever, are, and will continue to happen, there was no way we the best except hostile fuel. We make our enemies with fuel. We demo its fuel -yack, not demonstrate against the increase. If any increase in fuel demonstration, we will only skilled march. But if its fuel we hostile, we would be more creative to find a way out for this nation forward.

The best way is to use no more fuel. If we are not using the fuel, what we care about the things that also cause damage to the environment. Later, we behave like this : let him go up to as high as the monument continues to hang ! If we no longer use it, so what he is! Without any real movement to fight fuel, we would be horrified lifetime as it is now. Lifetime we should be ready to demonstrate. Lifetime we have not changed!

If you already know that the rest of our lives would tangled up fuel like it why do not we look the other way? Why do we give in to the state ? "Why?, Do not we have to fear that created this universe ? How many times God says " Afalaa ta'qiluuun?".

\section{References}

[1] Basri F, http://finance.detik.com/read/2012/01/04/181554/1806847/1 034/kuota-oil- subsidies - in - 2011- perforated - 13 million - kl. (1).

[2] EraMuslim.com. 2008, Article www.salafiyunpad.wordpress.com

[3] Bazwir : 2008, . http://www.eramuslim.com/berita/bc2/8527161342revrisond-baswir-kenaikan-bbm-cuma-alasan-ciptakanliberalisasi-sektor-migas.htm.

[4] Elijah Radianto, 2008, Presented to the " Open Class Academic Year 2008/2009 ", Universitas Kristen Indonesia Maluku, Ambon, September 8, 2008

[5] Rasche and Tatom, 1977, 1981, Burbidge and Harrison, 1984 ; Srtini, 1985, 1994; Gisser and Goodwin, 1986; Kim and Loungani, 1992, Raymond and Rich, 1997, Hamilton, 2000),

[6] Suparmoko, 2003, Principles of Microeconomics. PT. Group index. Scholastic. Jakarta

[7] Kamaludin, 2003, the Human Resource Management for Competitive Business.... Decisions in Supply Chain Management, Publisher IPB Press.
[8] Kamaluddin, 2003. Economics of Human Resources. Jakarta : PT. King. Grafindo Persada

[9] Handoko and Patriadi, 2005; Norton, 2004; Kasiyati, 2010, The Evaluation of Non - Fuel Subsidy Policy.The Study of Economy and Finance.9 ( 4 ).

[10] (Ferguson and Gould, 1975 in Astana, 2003),

[11] Charl and Kehoe, 2006, Modern Macroeconomics in Practice : How. Theory is..., Repository.ipb.ac.id /... / List \% 20Pustaka.pdf? Sequenc....

[12] Mankiew, 2003, Macro Economic, worth publisher

[13] Pohan A, 2008, Monetary policy framework and its implementation in Indonesia, Raja Grafindo Persada, Jakarta

[14] Stiglitz, 2013, " America, Free Markets, and the Sinking of the World Economy ". stevenyohanes.wordpress.com /... / recommendation.

[15] Kwik Kian Gie, 2006, the loss of political and economic policy of reason, Kompas, Jakarta

[16] http://www.eia.gov/petroleum/gasdiesel.

[17] http://www.mediafire.com/?jez4ynm4vzt (

[18] http://muslimdaily.net/opini/opini-17/anggito-abimanyu-. over-the-not-been-no-fuel-subsidy html

[19] Abhimanyu, A., 2000, Impact of Agriculture Trade and Subsidy Policy on the Macroeconomy, Distribution, and Environment in Indonesia : A Strategy for Future Industrial Development.The Developing Economies, 38 ( 4 ) : 547571.

[20] http://infoindonesia.wordpress.com/2009/06/30/ wealth-fornature-robbed-foreign-Indonesian - will - continue - poor /

[21] Ibrahim7 ], www.salafiyunpad.wordpress.com

[22] Ikhsan M, 2005, kolom.pacific.net.id /... / increase_price_oil...response..ht

[23] Arndt, H.W., and R.M. Sundrum, (1984 ), Devaluation and Inflation, Bulletin of Indonesian Economic Studies, Vol XX ( 1 ).

[24] http://energy.gov/articles/hows-and-whys-replacing-wholebarrel

[25] BP Migas : Indonesia's oil production 920 thousand bpd :

[26] Pertamina : Fuel consumption of " subsidies " in 2011 was 41.69 kilo liter

[27] http://finance.detik.com/read/2012/01/04/181554/1806847/1 034/kuota-oil- subsidies - in - 2011- perforated - 13 million $-\mathrm{kl}$ 